\title{
Assessment of Cadmium Contamination of Soils in Sewage Disposal Areas of Coimbatore District, Tamil Nadu, India
}

\author{
R. VINU RADHA*, K. KUMUTHA and P.MARIMUTHU \\ Department of Agricultural Microbiology, TamilNadu Agricultural University, \\ Coimbatore, Tamil Nadu, India.
}

http://dx.doi.org/10.12944/CWE.9.2.18

(Received: March 05, 2014; Accepted: May 04, 2014)

\begin{abstract}
Cadmium is a naturally occurring minor element, one of the metallic components in the earth's crust and oceans and present everywhere. Agricultural soils may also be enriched by cadmium which causes it's accumulation in plants and pose a potential threat to human health. Also high concentrations of cadmium in soil have detrimental effects on ecosystem as it enters the food chain. Soil samples were collected from different places near sewage disposal areas in Coimbatore where the source of cadmium is likely to be threatening the public. Twenty six samples were collected, their physiochemical properties and total cadmium content were determined. Five soil samples that showed high levels of more than $3 \mathrm{mg} \mathrm{kg}^{-1}$ of cadmium were identified as hotspots and their Arbuscularmycorrhizal spore count were assessed.
\end{abstract}

Key words: Cadmium contamination, Sewage disposal, Coimbatore, AM fungi.

\section{INTRODUCTION}

The most common heavy metal contaminations found in nature were $\mathrm{Cd}, \mathrm{Cr}, \mathrm{Cu}$, $\mathrm{Hg}, \mathrm{Pb}$ and $\mathrm{Ni}$. Environmental pollution by these heavy metals has become extensive due to industrial activities and when they go in elevated level in the environment, they are excessively absorbed by roots and translocated to shoot, leading to impaired metabolism and reduced growth. Heavy metal contamination in soil results in decreased soil microbial activity, soil fertility and yield losses. Cadmium is released into the biosphere naturally by volcanoes, weathering of rocks as well as anthropoegenically through various urban/industrial wastes such as mining and metal refining ${ }^{1}$, compost application ${ }^{2}$ and cadmium rich phosphate fertilizers ${ }^{3}$.

Increased concentrations of Cd in agricultural soils are known to come from human activities such as the application of phosphate fertilizer, sewage sludge, wastewater, and pesticides ${ }^{4,5,6}$, mining and smelting of metalliferous ores with high $\mathrm{Cd}$ content 7.

Determination of $\mathrm{Cd}$ in soil is very important for evaluating its environmental impact or its risk to agricultural production and soil health. According to the FOREGS geochemical database for European soils, the level of total cadmium concentration ranges between 0.06 and $0.6 \mathrm{ppm}$. However, the estimated cadmium values are below the most limiting threshold value of $1 \mathrm{ppm}$ for agricultural soils ${ }^{8}$. An accumulation of cadmium in soil will lead to an increase in pore water concentration and ultimately to increase in ground water and surface water concentrations.According to the Statutory Order $49 / 2000$, the soil quality criteria forcadmium is $0.5 \mathrm{mg} \mathrm{kg}^{-1}$ soil $^{9}$. Thismeans that areas applied with waste products must not exceed $0.5 \mathrm{mgCd} / \mathrm{kg} \mathrm{dw}$ in the plough layer. The criterion was mainly focused onsludge application. In the guidance document on waste products used foragricultural purposes, it is 
mentioned that the criterion value is assumednot to prevent the obtaining of sufficient areas for the use of waste products on agricultural soil ${ }^{10}$. The maximum target permissible level of cadmium according to the waste water quality guidelines for discharge into water bodies or water courses is less than $0.1 \mathrm{mg}$ $\mathrm{L}^{-111}$.

Cadmium induced effects include oxidative stress, genotoxicity, inhibition of photosynthetic activity and inhibition of root metabolism. The possible interactions between these modes of toxicity waswell explained ${ }^{12}$.Chlorosis, leaf rolls and stunting are the main and easily visible symptoms of cadmium toxicity in plants. There is a growing interest in problems concerning heavy metal contamination of cultivated lands and little is known regarding metal homeostasis and tolerance at the organismic level. For that reason, it is essential to clarify those problems related to metal transport, accumulation, detoxification and tolerance, and in this sense, it would be of enormous interest to use model systems other than plants, such asSaccharomyces pombe and Saccharomyces cereviciae, as well as the molecular analysis of hyperaccumulators like Arabidopsis halleri and some of the Thlaspi species $^{13}$.

The expected anthropogenic sources of cadmium in Coimbatore soils are more likely derived from a growing number of adverse anthropogenic sources viz., agricultural and urban runoff, garbage dumps, sewage disposals and gold making wastes.

The objectives of this research was to find out the hot spots of cadmium level in the contaminated areas of Coimbatore district, Tamil Nadu, India and explore the native microbial species viz., arbuscularmycorrhizal fungi and the plant growth promoting bacteria like Pseudomonas sp., etc. for cleaning up of contaminated sites.

\section{MATERIAL AND METHODS}

\section{Sampling sites}

Coimbatore (Tamil Nadu state, India) is located at $11.0161^{\circ} \mathrm{N}$ and $76.971^{\circ} \mathrm{E}$. Most areas in Coimbatore have a large number of open and covered sewage channels that are connected to each other which spread around the city premises. Almost all channels carry sewage disposed in an untreated form. The sampling locations were nearer to the places where sewage water and solid wastes are dumped for years together and collected from both barren and agricultural fields (Fig. 1). The samples were also collected from and near gold making waste disposed sewage areas (samples 20, 21 and 26) and sewage treated sludge sample (sample 7). Most of the agricultural lands where the soil samples were taken near the sewage disposal areas were cultivated with Palak greens and Amaranthus spp. as given in Table 1.

\section{Collection and Processing of soil samples}

Twenty six soil samples were collected from the nearby areas where sewage water go across the main cityand where it has been irrigated for years in farmers fields. Soil samples were collected from $0-15 \mathrm{~cm}$ depth and the sampling protocol to obtain a representative sample from a particular area was followed. The samples were air dried at $25-30^{\circ} \mathrm{C}$ for 2-4 days, ground to pass a $2 \mathrm{~mm}$ sieve, stored and labeled in sealed plastic bottles.

\section{Analysis of physico chemical properties of soil samples \\ Organic carbon in soil sample was} analysed by wet chromic acid digestion ${ }^{14}$. Total cadmium (Cd) was analysed by acid digestion method and estimated using Atomic Absorption Spectrophotometer with graphite furnace. $\mathrm{pH}$, EC and $C E C$, organic carbon were estimated as per the standard protocol.

\section{Isolation and screening of AM and PGPR from collected soil samples}

Plants in symbiosis with Arbuscular Mycorrhizal Fungi (AM) have the potential to take up cadmium from an enlarged soil volume and provide an attractive system to advance plant based environmental cleanup. Pseudomonas, a plant growth promoter present enormously in the rhizosphere supports the AM symbiosis and thus the combination of AM fungi andPseudomonasoffers suitable system towards the remediation of cadmium polluted soil.

ArbuscularMycorrhizal fungi as well as Pseudomonas were isolated from soils where 
cadmium concentration was found higher. Totally ten isolates of AM and Pseudomonas were obtained. AM isolates which were observed predominant have been selected for the study.Simultaneously Pseudomonas isolates were tested for IAA production and cadmium tolerance and the best one was selected for the further study.

\section{RESULTS AND DISCUSSION}

Observations on the physio-chemical properties showed considerable variations in different samples as specified in Table 2. The $\mathrm{pH}$ of almost all samples depicted that the soils were neutral to alkaline in nature which might be responsible for the poor solubility of this heavy metal. This was primarily due to the presence of base cationsfound naturally in soils, resulting in relatively high degree of base saturation.
Importance of soil $\mathrm{pH}$ value for availability of heavy metals to plants was reported ${ }^{15,16}$.Solubilityof heavy metals is highly $\mathrm{pH}$ dependent and, it increases with a decrease in soil $\mathrm{pH}$. Heavy metal sorption mechanisms in soils are influenced by soil $\mathrm{pH}$, and hence, soil sorption capacity will be greatly affected by any change in $\mathrm{pH}$. Various reasons have been reported ${ }^{17}$ for $\mathrm{pH}$-induced changes in the immobilization of metal ions in soils. Firstly, an increase in $\mathrm{pH}$ in variable charge soils causes an increase in surface negative charge resulting in an increase in cation $(\mathrm{Cd})$ adsorption. It was also reported ${ }^{18}$ that $\mathrm{CdOH}^{+}$species are formed above $\mathrm{pH} 8$ which have greater affinity for adsorption sites than just $\mathrm{Cd}^{2+}$.

The EC was found to be high $\left(>1.0 \mathrm{dSm}^{-1}\right)$ in samples showing high cadmium levels. The cadmium content of the soils can be positively correlated with

Table. 1: Collection of soil samples near different sewage disposed areas in Coimbatore

\begin{tabular}{lll}
\hline Sample No. & Location & Land description \\
\hline 1. & Velalur-1 & Agricultural land (Sorghum) \\
2. & Velalur-2 & Agricultural land (Bhendi) \\
3. & Velalur-3 & Agricultural land (Banana) \\
4. & Sungam -1 & Barren land \\
5. & Ukkadam-1 & Barren land \\
6. & Ukkadam-2 & Barren land \\
7. & Ukkadam-3 & Treated sewage sludge \\
8. & Ukkadam-4 & Treated sludge fertilized Marigold field \\
9. & Ukkadam-5 & Agricultural land (Palak field) \\
10. & Ukkadam-6 & Agricultural land (Amaranthus spp.) \\
11. & Selvapuram-1 & Agricultural land (Palak field) \\
12. & Selvapuram-2 & Agricultural land (Amaranthus spp.) \\
13. & Kovaipudur-1 & Agricultural land (Amaranthus spp.) \\
14. & Kovaipudur-2 & Agricultural land (Amaranthus spp.) \\
15. & Ukkadam-7 & Soil heap near sewage sludge \\
16. & Ukkadam-8 & Agricultural land (Palak greens) \\
17. & Ukkadam-9 & Agricultural land (Amaranthus spp.) \\
18. & Ukkadam-10 & Agricultural land (Amaranthus sp.) \\
19. & Ukkadam-11 & Soil heap near sewage sludge \\
20. & Ukkadam-12 & Gold making waste disposed sewage soil \\
21. & Ukkadam-13 & Soil heap near sewage sludge \\
22. & Ukkadam-14 & Agricultural land (Amaranthus spp.) \\
23. & Ukkadam-15 & Agricultural land (Amaranthus spp.) \\
24. & Ukkadam-16 & Agricultural land (Amaranthus spp.) \\
25. & Ukkadam-17 & Soil heap near sewage sludge \\
26. & Ukkadam-18 & Gold making waste disposed sewage soil \\
\hline & &
\end{tabular}


EC $\left(r^{2}=0.726\right)$ (excluding the samples $7,10,16,20,22$, 23,24, 25 and 26) which includes the treated sewage sludge (Fig. 2), sample taken from a soil heap near sewage sludge and from gold making waste disposed sewage soil $(n=17)$.. Similarly the cation exchange capacity of the sample 7 was so high $\left(135.9 \mathrm{cmol}\left(\mathrm{p}^{+}\right) \mathrm{kg}^{-1}\right.$ soil) which had a high cadmium level of $3.55 \mathrm{mgkg}^{-1}$ soil. Soils with high CECs are able to bind more cations such as $\mathrm{Ca}^{2+}$ or $\mathrm{K}^{+}$to the exchange sites of clay and organic matter particle surfaces. A high CEC soil will also have a greater buffering capacity, increasing the ability to resist changes in $\mathrm{pH}$. Soils with high amounts of clay and/ or organic matter will typically have higher CEC. The twenty six samples analysed in our study depicted a high CEC range of 20.1 to $136.0 \mathrm{cmol}\left(\mathrm{p}^{+}\right) \mathrm{kg}^{-1}$ soil which are not significantly correlated $(r=-0.0072)$. Butthe samples collected from agricultural and barren soils $(n=22)$ apart from the samples 16,20 , 21 and 26 were positively correlated $\left(r^{2}=0.629\right)$ with the cation exchange capacity (Fig. 3).This revealed the disparate relationship between the cadmium content and the native soil parameters and it may possibly be due to the recent practices of dumping sewage or gold making waste in a particular area. The report where cadmium level was significantly correlated with soil $\mathrm{pH}, \mathrm{EC}$, and $\mathrm{CEC}$ with respect to depth and cadmium availability index (CDI), which decreased with an increase in soil depth ${ }^{5}$ did not support the present investigation.

The anthropogenic sources of cadmium are related, first of all, to the influence of sewage sludge deposited at Ukkadam region in North Coimbatore and waste water released to the natural environment which may perhaps begin to pollute the ground

Table. 2: Physicochemical properties of collected soil samples

\begin{tabular}{lccccc}
\hline $\begin{array}{l}\text { Sample } \\
\text { No. }\end{array}$ & pH & $\begin{array}{c}\text { EC } \\
\left(\mathbf{d S} \mathbf{~ m}^{-1}\right)\end{array}$ & $\begin{array}{c}\text { Organic } \\
\text { Carbon }(\%)\end{array}$ & $\begin{array}{c}\text { CEC } \\
\text { cmol }\left(\mathbf{p}^{+}\right) \mathbf{k g}^{-1}\end{array}$ & $\begin{array}{c}\text { Cadmium } \\
\left.\text { content(mg } \mathbf{k g}^{-1}\right)\end{array}$ \\
\hline 1 & 8.06 & 0.06 & 0.44 & 24.4 & 0.80 \\
2 & 8.15 & 0.29 & 1.23 & 41.9 & 0.95 \\
3 & 8.13 & 0.27 & 1.49 & 34.1 & 0.80 \\
4 & 8.41 & 0.92 & 2.05 & 57.1 & 1.15 \\
5 & 8.22 & 0.86 & 2.84 & 73.7 & 1.35 \\
6 & 7.37 & 0.80 & 2.46 & 106.5 & 2.60 \\
7 & 7.08 & 0.95 & 18.79 & 136.0 & 3.55 \\
8 & 8.31 & 0.50 & 1.84 & 94.3 & 1.60 \\
9 & 8.11 & 0.82 & 2.46 & 65.7 & 1.72 \\
10 & 8.79 & 0.16 & 2.93 & 73.2 & 2.23 \\
11 & 8.06 & 0.51 & 0.12 & 30.7 & 1.65 \\
12 & 8.32 & 0.30 & 0.23 & 33.1 & 1.50 \\
13 & 7.46 & 0.63 & 0.75 & 28.2 & 1.40 \\
14 & 7.94 & 0.71 & 0.95 & 24.9 & 1.45 \\
15 & 8.14 & 1.23 & 0.06 & 45.8 & 1.65 \\
16 & 7.99 & 0.49 & 1.62 & 20.1 & 3.85 \\
17 & 8.46 & 0.81 & 1.27 & 42.0 & 0.95 \\
18 & 8.76 & 0.48 & 0.92 & 42.6 & 1.05 \\
19 & 8.65 & 0.97 & 0.46 & 39.9 & 1.25 \\
20 & 8.19 & 1.14 & 1.24 & 28.9 & 7.65 \\
21 & 7.39 & 2.69 & 5.48 & 48.8 & 4.55 \\
22 & 7.5 & 3.36 & 1.07 & 35.6 & 0.10 \\
23 & 8.62 & 2.08 & 1.01 & 30.5 & 0.40 \\
24 & 7.95 & 2.06 & 0.35 & 41.2 & 0.40 \\
25 & 7.94 & 0.52 & 2.02 & 32.3 & 1.35 \\
26 & 7.83 & 1.11 & 1.33 & 21.9 & 8.20 \\
\hline & & & & &
\end{tabular}


water by leaching down of this heavy metal to the subsurface soil during irrigation and other cultivation practices. The Palak field which was irrigated nearby the soil heap near sewage disposal area exhibited high level of cadmium content which was a good example for such possibility of contamination.

Soil organic matter is able to bind heavy metals. Comparatively the organic carbon was high $(18.79 \%)$ in the sewage sludge sample after treatment (sample 7). Enrichment of soil with organic matter could reduce the content of bioavailable metal species as a result of complexation of free ions of heavy metals. This process could be used for remediation to protect plants against metal pollution ${ }^{16}$.

The concentrations of cadmium was high (> $3.5 \mathrm{mg} \mathrm{kg}^{-1}$ ) in the soil samples where sewage sludge were applied in the fields. Cadmium level

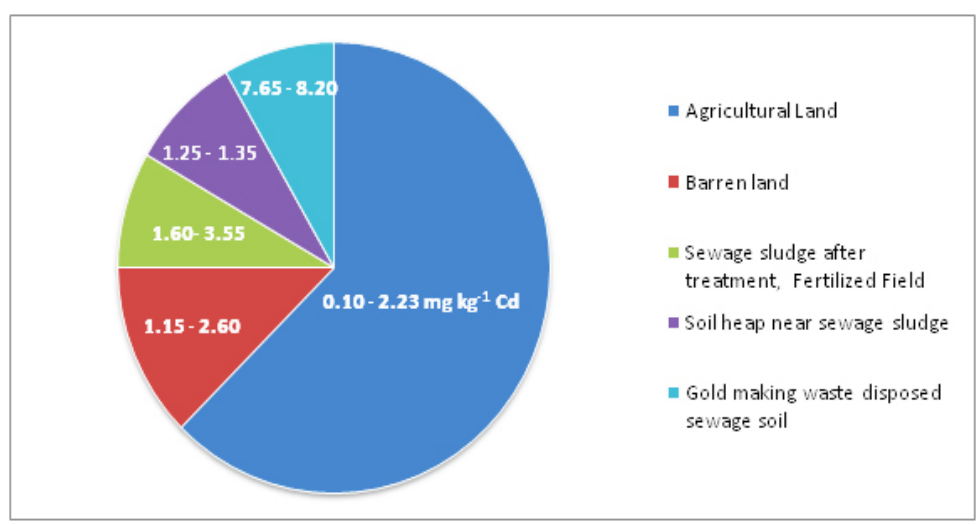

Fig.1: Cadmium concentrations (ppm) of different land (soil) type in sewage disposal areas of Coimbatore

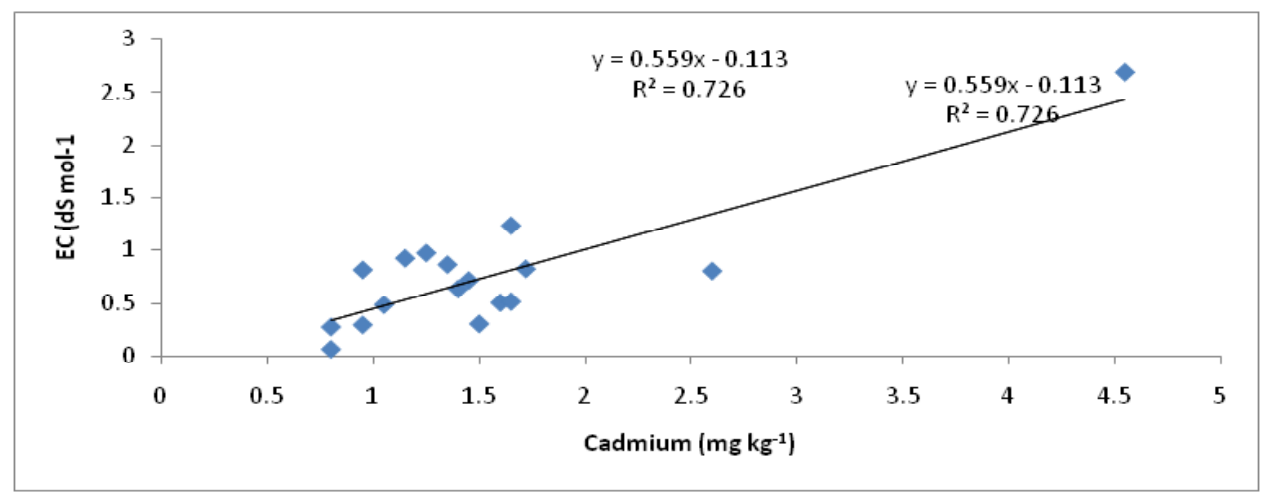

Fig. 2: Effect of soil EC on total Cd content of agricultural and barren soils $(n=17)$

Table. 3: Enumeration of AM spores from high cadmium content soils

\begin{tabular}{lccc}
\hline $\begin{array}{l}\text { Sample } \\
\text { No. }\end{array}$ & $\begin{array}{c}\text { Total } \\
\text { cadmium(mg kg-1) }\end{array}$ & $\begin{array}{c}\text { AM spore load } \\
\left(\text { No.) } \mathbf{1 0 0 ~ ~ ^ { - 1 }}\right.\end{array}$ & $\begin{array}{c}\text { Population of } \\
\text { Pseudomonas like } \\
\text { organisms(cfu g } \mathbf{~}^{-1} \text { ) }\end{array}$ \\
\hline 7 & 3.55 & 69 & $3 \times 10^{4}$ \\
16 & 3.85 & 52 & $3 \times 10^{4}$ \\
20 & 7.65 & 54 & $2 \times 10^{4}$ \\
21 & 4.55 & 51 & $1 \times 10^{4}$ \\
26 & 8.20 & 43 & $1 \times 10^{4}$ \\
\hline
\end{tabular}




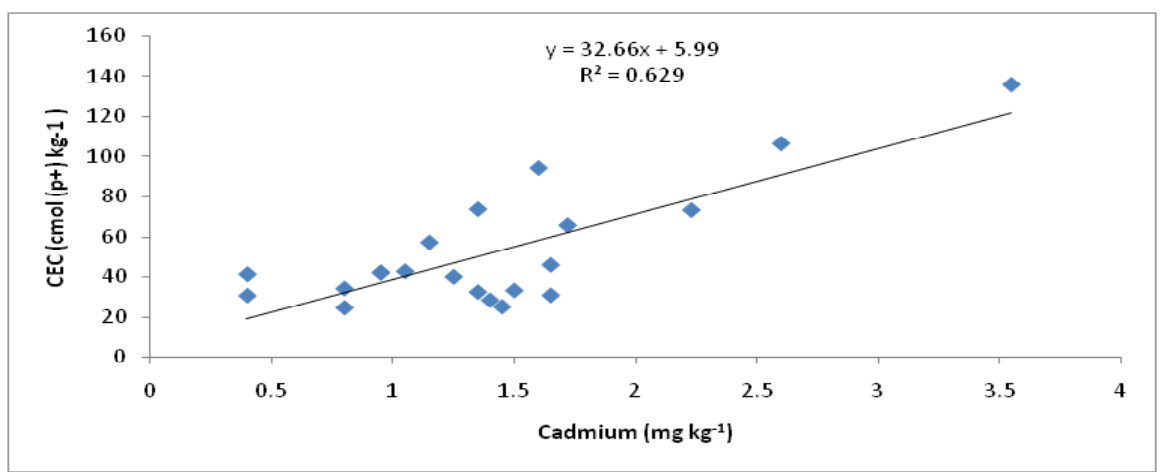

Fig. 3: Effect of CEC on total Cd content of agriculturaland barren soils $(n=22)$

was not positively correlated $(r=0.2277)$ with the organic carbon content because the organic carbon influenced the cadmium availability in the soil only when the soil was added with an amendment that is rich in organic carbon with an efficiency of metal immobilization as reported ${ }^{16}$. The high organic carbon content of soil in the treated sludge (Sample 7) would have highly immobilized the cadmium level which on other hand would have shot up the soil cadmium level posing a high risk in these area that has to be taken into consideration.

From the collected soil samples arbuscularmycorrhizal fungal spores and PGPRorganisms were isolated. The observations generally indicated that the number of AM spore load was low in cadmium rich soils than the soil which showed low cadmium content. This result was supported by the results obtained after application of cadmium whichshowed inhibition of the hyphal length of the arbuscular fungi Glomusmosseae and G. deserticola in vitro ${ }^{19}$.

Also cadmium content was high in samples due to direct sewage sludge dumping as soil heap in nearby agricultural fields (ranged from 4.5 to $8.2 \mathrm{mg}$ $\mathrm{kg}^{-1}$ ) and sewage water treated sludge application $\left(3.55 \mathrm{mg} \mathrm{kg}^{-1}\right)$. The nearby Amaranthus field (irrigated by well water as well as direct sewage water) and Marigold field (fertilized with treated sludge) were found with increasing level of cadmium

Cadmium in soils can be immobilized by increasing the soil $\mathrm{pH}$ through addition of liming materials ${ }^{20}$. Decrease in cadium uptake arise from increased $\mathrm{Cd}^{2+}$ adsorption caused by $\mathrm{pH}$, increase in negative charge, thereby decreasing its bioavailability. It is also recommended that soil $\mathrm{pH}$ be maintained at $\mathrm{pH} 6.5$ or greater in land receiving cadmium containing soil amendments such as phosphatic fertilizers and biosolids ${ }^{16}$. The bioavailability of $\mathrm{Cd}$ could be decreased by 2-3fold with ageing which may be attributed to increased immobilization ${ }^{18}$.

\section{CONCLUSION}

From the above study regarding cadmium contamination in sewage disposal areas of Coimbatore, it was important to report that despite high level of cadmium content in these areas, a significant proportion of added cadmium existed in a non-bioavailable pool in the soil. Moreover the soil physio-chemical properties were effectively correlated with the cadmium content in agricultural and barren fields. It varied quite substantially among the different land use locations. Exact mechanism in availability was not investigated.In due course of years there may be chances for the movement of cadmium into subsurface layer through leaching or soil diffusion mechanisms if this practice of sewage dumping takes place near the agricultural fields. The transfer of $\mathrm{Cd}$ to food chain can be managed through decreasing the bioavailability of cadmium by controlling sorption reactions.

\section{ACKNOWLEDGEMENT}

We would like to acknowledge the Department of Science and Technology, Ministry of Science and Technology, Government of India, New Delhi for the financial support of this 
project. The suggestions ofDr.K.Arulmozhiselvan, Professor of Soil Science and Agricultural Chemistry,
Tamil Nadu Agricultural University, Coimbatore regarding the presentation of is deeply honored and appreciated.

\section{REFERENCES}

1. Pandey S., Gupta K. and Mukharjee A.K., Impact of cadmium and lead on Catharanthusroseus- A phytoremediation study, J. Environ. Biol.,28 : 655-662 (2007).

2. Ramos M.C. and Lopez-Acevedo M., Zinc levels in vineyard soils from the Alt Penede'sAnoia region (NES pain) after compost application, Adv. Environ. Res ., 8 : 687-696 (2004).

3. Jiang D., Fei-bo W. and Guo-ping Z., Effects of cadmium on growth and photosynthesis of tomato seedlings. J. Zhejiang Uni Sci., 6 :974-980 (2005).

4. Chen T.B., Wong J.W.C., Zhou H.Y. and Wong M.H., Assessment of trace metal distribution and contamination in surface soils of Hong Kong. Environ Pollut.,96(1): 61-68 (1997).

5. Qadir M., Ghafoor A. and MurtazaG., Cadmium concentration in vegetables grown on urban soils irrigated with untreated municipal sewage, Environ Dev Sust., 2: 11-19 (2000).

6. de Meeus C, Eduljee, G.H. and Hutton M., Assessment and management of risks arising from exposure to cadmium in fertilizers I.Sci. Total Environ.,291(1-3): 167-187 (2002).

7. Tembo B.D., Sichilongo K. and Cernak J., Distribution of copper, lead, cadmium and zinc concentrations in soils around Kabwe town in Zambia. Chemosphere, 63 (3): 497-501 (2006).

8. Rodriguez Lado L., Hengl T. and Reuter H.I., Estimated cadmium concentration in agricultural soils: Total Cd concentration in ppm. FOREGS geochemical database for European Soils, JRC European Commission, Institute of Environment and Sustainability, Land Management and Natural Hazards Unit, Ispra,Italy. www.http://eusoils.jrc.ec.europa. eu (2010).

9. Miljø- ogEnergiministeriet: Bekendtgørelse om anvendel seafaffalds produktertiljordbrugsformål (Slambekendtgørelsen). Bek. nr.
49 af 20. January 2000. Miljø-og Energiministeriet(2000).

10. Danish EPA, Affaldsstoffertiljordbrugsformål. VejledningfraMiljøstyrelsen nr. 5, 1990. Vej. nr. 14005 af 01/06/1990, Miljøstyrelsen. (1990).

11. EPA, Summary of studies and on going activities which have relevance to UNEP Scientific review of lead and cadmium. In: Governing Council Decision 23/9 III : Review of Scientific Information on Lead and cadmium. Ref : HA 348/380/01/28, Accra, Ghana. $12^{\text {th }}$ June (2006).

12. Andresen E. and Kupper H., Cadmium toxicity in plants. In: Cadmium from toxicity to Essentiality, Metal Ions in Life Sciences. (Eds.) Sigel, A., Sigel, H. and R.K.O. Sigel. SpringerScience and Business media, Universitat Konstanz, Germany. Pp. 395 (2013).

13. Benavides M.P., Gallego S.M. and Tomaro M.L., Cadmium toxicity in plants. Braz. J. Plant Physiol., 17 (1): 21-34 (2005).

14. Walkley A. and Black C.A., An examination of the Deglgareff method for determining soil organic matter and proposed modification of chromic acid titration method. Soil Science, 37: 29-38 (1934).

15. Fytianos K., Katsianis G., Triantafyllou P. and Zachariadis G., Accumulation of heavy metals in vegetables grown in an industrial area in relation to soil. Bull. Environ. Contam. Toxicol. 67:423-430 (2001).

16. Skáodowski P., Maciejewska A. and Kwiatkowska J., The effect of organic matter from brown coal on bioavailability of heavy metals in contaminated soils, In : Soil and Water Pollution Monitoring, Protection and Remediation, (Eds.), I. Twardowskaet al. Springer Publications. Pp. 3 (2006).

17. Bolan N.S., Mahimairaja S., Kunhikrishnan, A. and Naidu, R., Sorption-bioavailability nexus of arsenic and cadmium in variable charge soils. J. Hazardous Materials (2012).

18. Naidu R., Bolan N.S., Kookana R.S. and 
Tiller, K.G., lonic strength and pH effects on the adsorption of cadmium and the surface charge of soils. Euro. J.Soil Sci., 45: 419- 429 (1994).

19. Arriagada C.A., Herrera M.A., Garcia Romera I. and Ocampo J.A., Tolerance to Cd of soybean (Glycine max) and Eucalyptus (Eucalyptus globules) inoculated with
ArbuscularMycorrhizal and saprobe Fungi. Symbiosis 36: 1-15.( 2004).

20. Hong C.O., Lee D.K., Chung D.Y. and Kim P.J., Liming effects on cadmium stabilization in upland soil affected by gold mining activity. Arch. Environ. Contam. Toxicol. 52: 502 (2007). 